\title{
Composing with Gaia: Isabelle Stengers and the Feminist Politics of the Earth
}

\author{
Miriam Tola
}

In her recent writings philosopher of science Isabelle Stengers reworks the figure of Gaia, the living planet, as a way to disrupt the fantasy of human exceptionalism and consider what political practices might open up livable worlds beyond the grip of capitalism. Building on, and simultaneously departing from, the work of scientists James Lovelock and Lynn Margulis, Stengers describes Gaia as an assemblage of forces largely indifferent to human reasons and projects, and draws attention to the multiple regimes of existence that characterize life on earth. If the prevalent narrative of the Anthropocene presents an undifferentiated human species as the dominant geological force on earth, ${ }^{1}$ Gaia is a figure for the post-Anthropocene that puts pressure on the idea of Man [sic] as the primary force making the world.

The first part of this essay situates Stengers's political use of Gaia theory in current debates on the Anthropocene. The second part considers how the figure of Gaia intersects with feminist attempts to challenge the Western divide between humans endowed with agency and malleable natural resources deprived of political relevance. I argue that Stengers's reworking of Gaia helps in reconsidering the relations between two bodies of feminist literature. The first body of work comprises a range of Deleuzian feminists who bring to the fore the earthly forces that enable and vastly exceed the scope of human existence. The second includes ecofeminist perspectives, including Marxist ecofeminism, that focus on the ways in which the current political economy feeds on the enclosure of social reproduction and nature's productivity. On this basis, I sketch the preliminary outline of a feminist politics of the earth interested in charting

\footnotetext{
${ }^{1}$ Paul Crutzen and his collaborators (Steffen et al, "The Anthropocene: Conceptual and Historical Perspectives") contend that the Anthropocene, the epoch of human influence on the planet began with the industrial revolution in the eighteenth-century, but it is only after World War II, with the great acceleration due to the intensive extraction of fossil fuels that the human species has become the dominant geophysical agent capable of altering the biogeochemical earth processes that characterized the relatively stable epoch of the Holocene.
} 
a passage from an ontology of pure difference to an art of composition pursuing the radical reconfiguration of the particular entanglement of human and earthly forces that goes under the name of fossil-fuel capitalism.

\section{Gaia's Multiple Regimes of Existence}

Isabelle Stengers's interest in complicating established ways to conceive nature, society and politics can be traced back to her collaboration with physicist Ilya Prigogine, a pioneering figure of chaos theory. Their book Order Out of Chaos (1984) challenges the idea of homeostasis with the analysis of phase changes at the molecular level of organization. They describe an active matter, characterized by the sudden and irreversible emergence of organized structures out of highly turbulent situations. What appears as pure chaos at the macroscopic level corresponds to processes of self-organization at the molecular level that might produce dissipative structures, new dynamic states of matter always embedded in unstable situations of non-equilibrium. Prigogine and Stengers claim that, through the rearticulation of time and nature, the view of molecular and cosmological processes that have enabled the emergence and variation of life forms on earth, has shifted "toward the multiple, the temporal, and the complex" (292). In focusing on tendencies toward unpredictability and differentiation at the physical, biological and chemical level, Prigogine and Stengers suggest that, rather than functioning as inert backdrop for human actions, the ever-changing complexity of nature precedes that of society.

In many ways Stengers's recent work radicalizes this insight by addressing some of the most pressing issues of our time: climate change, capitalist capture, and political activism. In the book In Catastrophic Times (2015), first published in 2009, Stengers turns to an unprecedented form of impingement identified with the controversial figure of Gaia, the living planet. Stengers argues that we are suspended between two histories. The first presents economic growth as inescapable horizon, and the only way out from ecological and economic crisis. The second history envisions a bifurcation between "barbarism" and the creation of liveable worlds. Barbaric scenarios are produced at the intersection between the unfolding of climate change and the capitalist attempt to turn extreme weather events into opportunities for profit. From private disaster management, to the creation of low-carbon markets and services, to ecosystem services, and the fast-growing business of weather derivatives, the ecological crisis is rapidly becoming a money-spinner (Cooper, "Turbulent Worlds"). Gaia emerges in this second history as an intruder, a figure of the earth that dislodges the anthropos, the undifferentiated human species, from its commanding position. What draws Stengers to 
such an image? Before responding to this question directly, I turn to the risks of invoking Gaia theory.

Gaia theory emerged in the 1970s when British atmospheric scientist James Lovelock, then working for the NASA space program, proposed that the earth exists as a cybernetic system with homeostatic tendencies. Working closely with Lovelock, American microbiologist Lynn Margulis explained Gaia as a microbial phenomenon, the expression of the symbiotic activities of bacteria that have enabled the emergence of life on the planet. The Gaia hypothesis, the notion of the earth as system with self-regulating capacities, was received with scepticism in scientific circles and sometimes dismissed as teleological speculation. It did not help that deep ecologists and religious groups turned Gaia theory into the image of the planet as benevolent whole. In his writings on climate change Lovelock draws far-reaching political conclusions about human relationships with Gaia. He goes as far as to suggest that the living planet is now ready to strike back against those who caused her suffering. According to this view, humans are facing an implacable "Earthly enemy," and governments must be ready to undertake massive technological interventions, and even suppress part of the freedom of their citizens in the name of ecological security (Lovelock 153). To be sure, Gaia is a concept loaded with problematic connotations. It is connected both to the image of the earth as purposeful organism, and to deep ecologist inclinations to overlook the "inequalities within human society" (Guha 72) in the name of a dehistoricized nature. Approaching this subject, depicted by some as the quintessential figure of organicism, is fraught with many dangers. Why then would Stengers enter this slippery terrain?

It is her contention that the risks involved in engaging with the intrusion of Gaia are worth taking. What is perhaps most attractive in the Gaia hypothesis is that it presents humans as neither the owners nor the stewards of the planet. In Lynn Margulis' words:

Gaia is not the nurturing mother or fertility doll of the human race. Rather, human beings, in spite of our raging anthropocentrism, are relegated to a tiny and unessential part of the Gaian system. People, like brontosauruses and grassland, are merely one of the many weedy components of an enormous living system dominated by microbes. (Margulis and Sagan 183)

Thus, the first step in Stengers's risky account of Gaia is to redefine it in terms that are closer to Margulis' bottom-up microbial perspective than Lovelock's top-down view of the earth through NASA telescopes. In Catastrophic Times she writes: "That on which we depend, and which has so often been defined as the 'given,' the globally stable context of our histories and our calculations, is the product of a history of co-evolution, 
the first artisans and real, continuing actors of which were the innumerable populations of microorganisms "(44). While Lovelock often returns to the self-regulating capacity of the planet to keep the climate and the chemistry of the planet at a comfortable level for whatever form of life inhabiting it, Stengers stresses a rather different aspect of Gaia, who

... makes the epic versions of human history, in which Man, standing up on his hind legs and learning to decipher the laws of nature, understands that he is the master of his own fate, free from any transcendence, look rather old. Gaia is the name of an unprecedented or forgotten form of transcendence: a transcendence deprived of the noble qualities that would allow it to be invoked as an arbiter, guarantor, or resource; a ticklish assemblage of forces that are indifferent to our reasons and our projects. (47)

Here Stengers complements the reference to Gaia as a living planet-a concept created within the sciences - with the non-scientific reference to Gaia as a form of "transcendence deprived of noble qualities," the chthonic deity that Greek mythology associated with matters of creation and destruction. Gaia, however, cannot be assimilated to a deity or a goddess precisely because it inhabits the disparate domains of science and non-science that are often at odds with each other. What is important is that both meanings of Gaia - the living planet and the pre-modern form of transcendence - disrupt the idea of the human as self-inventive being that undergirds much of the Anthropocene narrative. In this sense, Stengers's reworking of Gaia is close to Donna Haraway's recent proposal to use Chthulucene $^{2}$ as the name for a "timespace" that troubles the universalist anthropos of the Anthropocene. Chthulucene is a feminist version of Cthulhu, the monster imagined by H.P. Lovecraft. It approximates the "earth-wide tentacular powers" ("Anthropocene, Capitalocene" 60) of non-modern figures such as the Inka Pachamama, the Navajo Spider OldWoman. Both Gaia and Chthulucene are concerned with world-making, a matter of divergent and overlapping activities, often unintentional, many of which exist irrespective of human control. ${ }^{3}$

\footnotetext{
${ }^{2}$ Haraway has also proposed Capitalocene as a name for the current epoch. This term emphasizes that ecological destruction is not a species-problem but depends on capitalist development ("Anthropocene, Capitalocene"). Fully articulating the Capitalocene from a Marxist perspective that focuses on the dialectical relation between human labor and nature, Jason Moore dismisses the Anthropocene as "fashionable concept" (Moore, Capitalism in the Web of Life 170). The problem with Moore's version of the Capitalocene, however, is that, in contrast with Gaia and Chthulucene, it foregrounds capitalist relations that transform nature without paying much attention to nature as power of mutation.

${ }^{3}$ For an ethnographically inflected theory of world-making see Anna Tsing's inspiring The Mushroom at the End of the World (2015).
} 
In spite of Lovelock's warnings about the "revenge of Gaia," in Stengers's account the earth is neither fragile nor intentionally threatening, neither a benign, maternal organism nor a vindictive entity. It has no goal and no intentionality, and exists irrespectively of human presence. As Stengers puts it eloquently: "Of the Earth, the present subject of our scenarios, we can presuppose a single thing: it doesn't care about the questions we ask about it" (The Invention of Modern Science 145). In contrast to those beings whose existence is the result of processes of coconstitution with humans, the planet itself, with its plate tectonics, its rocks and the bacteria that sustain the biosphere by connecting the living and the nonliving, presents an eventfulness beyond the scope of human involvement (Hird, "Indifferent Globality"). Of course, reducing Gaia to a set of resources available for commodity production has a cost and potentially lethal consequences for many species. But Gaia itself is not in danger since "her innumerable co-authors, the microorganisms, will effectively continue to participate in her regime of existence, that of a living planet" (Stengers, In Catastrophic Times 47). Thus thinking Gaia in Stengers' terms means thinking life beyond the human, and thinking the human as a particular and contingent weaving of material and social forms. Thinking in the presence of Gaia means to shift away from the idea of nature as available to human manipulation, to the earth as fundamentally unstable, composed of assemblages involving more-thanhuman beings and forces. It suggests that although the transformations in the earth processes that characterize the Anthropocene are the result of anthropogenic changes, they arise out of a metastable milieu of which humans do not have full control. To be clear, I do not want to suggest for a moment that anthropogenic change is not happening. Nor am I suggesting, as the lobbyists for Big Oil do, that the resilience of ecosystems will fix ecological disasters (Nixon 21-22). Rather, the question is that "from the viewpoint of the long history of the Earth itself" the ecological transformation that humans can provoke "will be one more "contingent event' in a long series. What we will call a 'catastrophe' will be, for it, a contingency" (Stengers, The Invention of Modern Science 145).

Of course this contingent event presents significant challenges in that it indicates the possibility of the gradual eradication not of life on the planet but of the regimes of terrestrial existence we depend on, of that particular milieu that made human life possible. Reflecting upon the symbiotic activity of bacteria that exists regardless of human life and of which humans do not even know about, Myra Hird observes: "Gaia theory's key insight here is the indifference of nonhuman life to human life; in other words, humanity's utter dependence upon, and vulnerability to, nonhuman life and nonlife" ("Indifferent Globality" 63). At the time of climate change, when the last residues of the modern paradigm of nature ordered by universal laws have been displaced by the irruption of nature as multiple vectors of uncertainty, it is becoming clear that there is no 
reciprocity between a highly differentiated human species, and what we call nature. On the contrary, there are patterns of non-symmetry, of irreducible difference, that challenge any notion of restoring nature's equilibrium by means of technological fixes.

In this sense, Stengers's reworking of Gaia poses profound challenges to the prevalent discourses of the Anthropocene. Scientific accounts of the Anthropocene foreground the geological agency of the human species, its power to impact but also fundamentally re-direct planetary processes. Some proponents of the Anthropocene see the perils of the new age as sources of opportunities for shaping the future of the planet. American ecologist Erle Ellis, for one, rejects the view of the Anthropocene as crisis and celebrates instead the advent of the "good Anthropocene," that is, "a new geological epoch ripe with human-directed opportunity" (44). British environmental journalist Mark Lynas is even more eloquent: "Nature no longer runs the Earth. We do. It is our choice what happens here" (8). This muscular assertion of mastery over nature is sometimes intended as a call to action to avert a dangerous tipping point in the ongoing environmental crisis. It assumes that humans are the stewards of the earth or, in a twist that reflects the pervasiveness of neoliberal rationality, planet managers capable of converting scientific expertise into appropriate governance tools and technological fixes. Posing the problem of biospheric transformation primarily in terms of establishing quantifiable metrics to calculate risk, this approach tends to favor measures such as the dramatic scaling up of nuclear power and geo-engineering interventions aimed at altering planetary processes. The idea is that since the earth has gone out of balance, humans must intervene to restore stability. Needless to say, such interventions leave unchallenged the effects of the intensification of extractive economies, financialization and indebtedness.

Other analysts of the proposed naming of the Anthropocene era show a cautious attitude about scientific attempts to manipulate geophysics dynamics. They are less prone to universalistic claims about the influence of a presumed unitary humanity - the anthropos-on the planet. For example, Steffen et al, go as far as to argue that the new concept challenges "the belief systems and assumptions that underpin neoclassical economic thinking, which in turn has been a major driver of the Great Acceleration" (862). Yet, even in these cases the emphasis falls back on the urgency to act at the level of global governance. Although heterogeneous and in some ways open to interdisciplinary exchanges, much scientific discourse on the Anthropocene sustains a more and more anachronistic narrative of redemption and salvation, the idea that a generic human species has the capability and the scientific knowledge to redirect global change toward a good Anthropocene. Despite a series of utterly disappointing climate summits, global governance and scientific expertise are still presented as the key solutions to the problems posed by the 
Anthropocene. Some scientists and governance experts have teamed up to advocate upgrading environmental agencies at the United Nations. Other options range from the creation of a global environmental organization modeled after the World Trade Organization, to a more centralized intergovernmental agency equipped with enforcement powers.

Stengers's observation that governance by experts and the management of populations has replaced politics aptly characterizes the present context. She writes: "We deal no longer with politics but with governance - with situations deprived of the power to force thinking as they are defined by stakeholders' vested interests" ("Including Nonhumans in Political Theory" 20). Stengers is not alone in her criticism of a post-political condition that replaces conflicts around socio-ecological configurations with managerial planning and technological fixes. The geographer Erik Swyngedouw, for example, claims that environmental policy is a key arena for the construction of a post-political regime that subordinates disagreement and adversarial politics to technocratic approaches. But while Swyngedouw and other theorists of post-politics call for the displacement of environmental policing into the terrain of the "properly political" (71), Stengers is interested in reconfiguring politics to account for the ways in which more-than-human existents produce feelings, thought and action. In Stengers's words, Gaia heralds

... that those who believed they were at the centre desperately mess up what they, and many other earthly critters, depend upon. Now those of us who were told stories since birth that there is something really special in being "human" are at a bifurcation point: either we furiously keep to that narrative, or we accept that if there is a post-Anthropocene worth living in, those who will live in it will need different stories, with no entity at the centre of the stage. ("Matters of Cosmopolitics" 178)

If the Anthropocene configures the human as geological force in its own right, the intrusion of Gaia draws attention on the earth's multiple regimes of existence and thus resists the notion of the primacy of human agency in the transformation of the world.

\section{Stengers, Feminism, and the Politics of the Earth}

For Stengers, the reworking of Gaia is part of a cosmopolitical project aimed at complicating the Western understanding of politics as the gathering of sovereign individuals capable of making judgements in the interest of the community (Stengers "The Cosmopolitical Proposal"). The prefix "cosmos" signals the impossibility of representing what is proper in the human and should not be confused with the Kantian ideal of a good common world. "Cosmos" is meant to make explicit the presence of the 
disparate entities and beings that are left out of the terrain of the political. ${ }^{4}$ From this perspective, her work is particularly significant in the context of the current rematerialization of political theory (Braun and Whatmore, Political Matter).

But how does Stengers's cosmopolitical proposal intersect with feminism? Until recently her relation to feminist theory has been peripheral and discontinuous. Her early writings on the sciences presented scant interactions with feminist epistemologies. When she did engage feminism, it was usually to underscore the limits of critical methodologies that code science as inherently masculine or "as the simple, monotonous, and hopeless effects of the force of purely social relations" (Stengers, "Another Look: Relearning to Laugh" 43). Despite sharing the feminist concern for the arrogance of science in disqualifying propositions that do not conform to scientific knowledge, Stengers also draws attention to the adventurous aspect of practices dealing with the recalcitrance of the world to submit to scientific models. In recent years, Stengers's debt to feminism has become explicit. Feminism, she declares, has played a constitutive and vital role in her educational and affective trajectories (Stengers, "Matters of Cosmopolitics" 178). As I have already mentioned, her meditation on Gaia presents an ongoing exchange with Donna Haraway's writings on Chthulucene. Still, as Elizabeth Wilson points out "Exactly what might mark this work as feminist remains elusive, and generatively so" (39). Wilson's argument is that Stengers challenges feminists to reinvigorate the analysis of science through positive affects. Here, I want to suggest that the cross-pollination between Stengers's cosmopolitics and feminism might prove fruitful for the elaboration of what I call a feminist politics of composition with/in the earth, that is, a politics that moves beyond the image of the self-making hu-man but still pursues the project of organizing collective powers and pleasures with/in the earthly milieu.

Stengers's work is useful to bring into conversation two bodies of feminist literature whose relation may need reconsideration. The first is the body of writing expressed by a diverse community of feminist scholars working within a Deleuzian framework to dismantle the notion of bounded human subjects separated from the material world. These ontological orientations focus on the indeterminacy of generative processes that

${ }^{4}$ Stengers's cosmopolitics offers an indirect counter-point to Dipesh Chakrabarty's puzzling reinstatement of binary thinking in his reflection on the Anthropocene. He argues that the Anthropocene has doubled the figure of the human: the human-human and the human as geo-physical agent. While the former is endowed with a sense of ontology and therefore is concerned with the pursuit of justice, the latter has no ontological dimension and is thus justice-blind ("Postcolonial Studies and the Challenge of Climate Change"). It seems to me that this distinction reaffirms the idea of a mute world whose forces do not pose ethical-political problems and questions. 
compose highly differentiated humans along with a multiplicity of other existents. The second body of literature consists of ecofeminist analyses of the linkages between modes of enclosing the productivity of nature and the exploitation of gendered and racialized subjects in the process of capitalist accumulation. Each of these orientations has its own key figures and debates, and they are rarely brought into productive conversation. Yet, it seems to me that there is much to be gained, in terms of analysis and politics, from engagements that intertwine feminist ontologies of life and ecofeminist concerns for the privatization and marketization of nature.

The image of Gaia as indifferent and impersonal force proffered by Stengers overlaps interestingly with contemporary feminist ontologies that emphasize asymmetry and difference as key modes for understanding the emergence and variation of lifelines. In Elizabeth Grosz's exploration of sexual difference as vector pointing toward a reframing of biology and nature, the earth emerges as a field of forces indifferent to the human species that nevertheless impinges on our sensations, actions, and thoughts. Grosz suggests that the forces of the earth-atmospheric forces, oceanic tides, geography, gravity, temporality, "impinge on, transform, and become the objects for living beings" (Grosz, Chaos, Territory, Art 102). In turn, living beings harness and transform them to give rise to provisional zones of cohesion, conceptual formations, bodily habits and modes of being together. Thus, the capacity for inventing the new, traditionally associated with the human, becomes the modus operandi of nature and the earth, that which makes us become other than ourselves. Grosz's foregrounding of the indeterminacy of chaotic cosmic forces, the real that exists beyond human control, points towards a politics of renaturalization that "seeks the nonhuman forces operating within everything we think is ours, or our own doing" (Sharp 9). If Grosz goes as far as to claim that culture can be thought of as an extension of nature's power of mutation (Nick of Time 91), Rosi Braidotti suggests that nature and culture need to be thought as a combination of biosocial forces that co-produce each other. Braidotti attempts to dismantle the entrenched philosophical habit of hierarchically distinguishing between given material existence (zoé) and the creative realm of the social (bios) ${ }^{5}$, by foregrounding the vitality of zoé, the surplus generativity of matter. She points out that in the same way that sexual difference has been rendered in pejorative terms as the "other" of Man, zoé has been thought in opposition to bios, that is, the human sphere of ethics, politics and social life. As such, zoé has been historically feminized: "women were classified

\footnotetext{
${ }^{5}$ Braidotti offers a pointed criticism of Giorgio Agamben's conceptualization of zoé as bare life. She argues that by identifying zoé with death and the vulnerability of life, Agamben forecloses any possibility of transformation (Transpositions).
} 
alongside natives, animals and others as referents of a generative force that was reduced to a mere biological function and deprived of political and ethical relevance" (Transpositions 270). For Braidotti the commitment to the emergent properties of life implies a shift in the understanding of subjectivity. She writes: "We need to visualize the subject as a transversal entity encompassing the human, our genetic neighbors the animals and the earth as a whole" (Braidotti, The Posthuman 82). In Braidotti's dethroning of the anthropos as the sovereign subject of history, the celebration of the vitality of matter is linked to the theorization of the subject as assemblage emerging out of the nature-culture continuum. She asks: "What would a geo-centred subject look like?" (81).

These feminist frameworks, heavily influenced by Deleuze and Guattari, privilege the inhuman potentialities that give rise to embodied forms of life over bounded human subjects (Colebrook, Deleuze and the Meaning of Life). In this sense, they mark a striking break with the view of the human as a "dominion within a dominion" that Spinoza called into question. However, the problem remains as to whether such rich conceptualization of nature, life, and the earth can contribute to forms of collective action. How to move from the mesmerizing effects of the chaotic unfolding of life to collective practices pursuing the subtraction from capitalist arrangements of eco-social relations? This is the question that interests Stengers, the one she raises by invoking the intrusion of Gaia. An implacable and highly impersonal force, Gaia does not demand anything but poses an intractable problem, a political problem, to which "we" might or might not respond. This problem is how to live otherwise, how to compose with earth processes that are affected by human activity and have the power to affect "us" in unpredictable and uncontrollable ways. For Stengers,

... the new figure of Gaia indicates that it is becoming urgent to create a contrast between the earth valorized as a set of resources and the earth taken into account as a set of interdependent processes, capable of assemblages that are very different from the ones on which we depend. (Stengers, Thinking With Whitehead 163)

In addressing the limits of reducing the earth to a set of resources and raw materials, Stengers offers a trenchant critique of the dominant liberal tradition deriving from Locke that sees the planet as an inexhaustible repository of resources to be transformed into value through labor and enclosures. She is adamant that the problems posed by the intrusion of Gaia entail a radical rethinking of Euro-American hegemonic notions of progress and growth that have emerged out of a colonial landscape marked by the violent disqualification of other ways of living and conceiving the world. 
In this respect, Stengers shares a number of affinities with ecofeminist concerns for the creation of modes of living disentangled from capitalist development. Developing a range of heterogenous and contested perspectives, ecofeminists have offered important insights on the connections between the capitalist plundering of the earth and gendered and racialized forms of dispossession. ${ }^{6}$ Stengers's work intersects the activist witchcraft of Starhawk (I will return to this in the following section) and Vandana Shiva's opposition to the privatization of life. Her interest in ongoing processes of enclosures and the political potential of the commons (Stengers, In Catastrophic Times 79-105) also brings her into dialogue with scholar-activists such as Silvia Federici and Mariarosa Dalla Costa. Although Dalla Costa and Federici are usually associated with Marxist feminism, their investigation of the capitalist appropriation of so-called externalities to the market has extended from women's domestic labor to broader questions of eco-social reproduction (Federici, Revolution at Point Zero; Dalla Costa, Our Mother Ocean). These scholars' exploration of the linkages between the repercussions of new waves of enclosures along patterns of gender and the disqualification of non-capitalist conceptions of the material world, is an important point of departure for contemporary analysis of the ways in which "life itself" has become enmeshed in the circuits of capitalist accumulation (Cooper, Life As Surplus). Their work especially resonates with Stengers's concern for learning from Marx's vital critique of capitalism without embracing Marxist teleological narratives of economic growth (Stengers, In Catastrophic Times 51-59).

Dalla Costa's recent writings, for example, document the struggles of the World Fisher Movement since its inception in Southern India to the present as a form of resistance to the ecological exhaustion provoked by the neoliberal enclosures of land and the seas (Dalla Costa, Our Mother Ocean). She defines the ocean as a commons whose regenerative powers must be supported by the cooperation between humans and nature. Dalla Costa's position here is in line with Carolyn Merchant's call for a "partnership ethics" grounded in relationality and reciprocity that understands humans and nonhuman nature as equal partners able to cooperate in the achievement of mutual survival (Earthcare). Similarly, in the book Earth Democracy (2006), Vandana Shiva celebrates the image of the "Earth family" by which she means the community of beings supported by Mother Earth. Her argument is that the care of the commons, the earth that we share with nonhuman living beings, would require

\footnotetext{
'In "Ecofeminism Revisited" (2011), Greta Gaard provides a stimulating account of the contributions of ecofeminism from the 1980s onward. Emphasizing the ecofeminist insights on the connections between racism, sexism and the appropriation of nature, she proposes to retrieve ecofeminism as foundational for much of current feminist scholarship regarding socio-natural entanglements.
} 
attention and appreciation for the life-sustaining practices performed at the level of the local, particularly by women and indigenous groups in the Southern hemisphere. The making of the commons would proceed hand in hand with a "reenchantment of the world," a consideration of nature as harmonious whole, capable of regeneration and dynamic equilibrium.

Such ecofeminist formulations are not devoid of problems. They seem to view nature as a homeostatic cycle whose harmony needs to be restored, but this is difficult to sustain in light of the existence of positive feedback loops and irreversible "tipping points" that characterize complex systems. Further, the alignment between atmospheric and oceanic forces and the universalized figure of the nurturing and benign mother remains problematic for many feminists.

To be sure, Stengers's figure of Gaia complicates Dalla Costa and Shiva's view of nature. Gaia is neither a nurturing mother nor a partner open to negotiations. It is an ensemble of concatenated differences characterized by tendencies toward perturbation that the intensification of the commodity economy amplifies but is not capable of controlling. Nevertheless, Stengers refuses to reduce ecofeminism to a monolithic paradigm that opposes the nurturing qualities associated to women and nature to a masculine technoscience. For example, she suggests that those feminists who dismiss Vandana Shiva as essentialist fall in the trap of putting themselves in the position of judging how proper feminist knowledge should be produced. Therefore, they reiterate one of the characteristic habits of thought of Western modernity: the distinction between those who know and those who believe (Stengers, "Experimenting With Refrains" 41-42). What gets lost is the ability to engage with the pressing issues addressed by Shiva's activism. Key among them is the call for a science capable of taking into account landuse practices and knowledges that are destroyed in the name of progress. This is why Stengers incorporates a certain ecofeminist sensibility into the reworking of Gaia, one that attempts to foster resistance to the current political economy that proliferates and feeds on practices only to reorganize or discard them when they are no longer needed. As Stengers makes clear:

The only truly tolerant and relativist undertaking that I know of is capitalism. It alone is capable of radically aligning disparate practices and values only to turn against those whose destruction would be of interest for it; for it is radically indifferent to whatever binds them and is itself bound by nothing, even its own axioms of the moment. (Stengers, Cosmopolitics II 74)

By characterizing Gaia as an intruder, Stengers foregrounds powers of becoming that are indifferent to human projects. In this sense, this figuration of the earth is close to feminist ontologies that see the human as 
one among many of the trajectories that life on the planet has developed. But when she argues that Gaia poses the problem of how to live otherwise, she also reactivates the ecofeminist attentiveness to the destruction of practices in the context of historically specific capitalist arrangements of eco-social relations. Thus, the figure of Gaia intersects strands of feminist thought that have rarely been brought together.

The feminist orientations examined in this section offer capacious and inventive accounts of human embeddedness in a material world that enables the existence of a multiplicity of forms of life. My intention is not to propose an easy alignment between these disparate feminist streams, but I am interested in troubling the linearity of Western feminist storytelling (Hemmings, Why Stories Matter) that positions ecofeminism as belonging to a history that has been superseded by more sophisticated feminist tendencies. Thus, I argue that both feminist ontologies of life and ecofeminist tendencies are relevant for articulating political projects for the present time. Specifically, they provide rich resources for the elaboration of a politics of composition within the earth that slows down reasoning around the Anthropocene by disturbing the notion of the human as primary agent of earth's becoming. Here, I suggest three preliminary and evolving propositions showing how the intertwining of these divergent feminist strands contributes to developing a feminist politics of the earth. First, such politics is inspired by feminist philosophies that break away from the modern habit of presenting nature as the backdrop for Man's action; it reframes the earth as a power of mutation rather than the material substratum transformed by human intervention. Second, a feminist politics of the earth is indebted to ecofeminism in that it cultivates a genealogical awareness of the entanglement between processes of feminization, racialization and the ongoing privatization of nature. Third, and this is the topic of the following section, it envisions activist arrangements that disrupt the modern Western distinction between human actors and a manipulable natural world deprived of political relevance.

\section{Composing with Gaia}

In a somewhat enigmatic formula, Stengers suggests that "we" need to learn to compose with Gaia. What does this mean? The hesitation about the redemptive narrative of the good Anthropocene does not need to coincide with the embrace of powerlessness. On the contrary, it might open up the space for new modes of engagement with the problems posed by the intrusion of Gaia. Learning to compose with Gaia, however, has little to do with a project of reconciliation between humans and the planet after centuries of capitalist exploitation. Composition does not imply a relation of reciprocity and partnership with nonhuman companions in the achievement of mutual benefit. Rather, a process of composition might 
arise when "we," that is, a collective that can only emerge out of situated struggles, begin to think and act not as self-sufficient subjects but through asymmetric attachments to others that are not necessarily human.

The concept of composition has a rich genealogy that cuts across Spinozism, Autonomist Marxism, the philosophy of Deleuze and Guattari, and science studies. For Autonomist theorists Michael Hardt and Antonio Negri, for instance, composition refers to the conflicting and cooperative interplay of singularities in the common, and ultimately designates a process of organization of human living labor that exceeds the institutional mechanisms of representative democracy. While in Hardt and Negri's "ecology of the common" the divide of nature and culture remains fundamentally unchallenged in that they envision a wildly autopoietic human multitude engaged in the re/production and management of nature (Hardt and Negri, Commonwealth) in science studies composition has become a theoretical tool for contesting the bifurcation between nature and politics.

In his meditation on composition, Bruno Latour argues that politics consists of reassembling that which Western modernity has divided, that is, a natural order made up of passive objects that speak through science, and a social order resulting from the interaction of autonomous individuals that speak through politics (Latour, Politics of Nature). Building on Viveiros de Castro's critique of Western mononaturalism, ${ }^{7}$ Latour contends that there is no such thing as a given nature, a common world shared by humans, a world of facts to be reconciled with a world of values. Rather, a common world needs to be composed; it has to emerge out of a space of indistinction between subjects and objects. Politics consists precisely in the composition of this common world; it is the activity of bringing together utterly heterogeneous parts in a whole open to continuous reconfiguration (Latour, "An Attempt at a 'Compositionist Manifesto"').

Strikingly for a non-modern theorist, Latour's compositionism largely relies on the most distinctive political form of European modernity: representative democracy. From the metaphor of the "Parliament of Things" introduced in the early 1990s, to the bicameral model presented in The Politics of Nature (2004), Latour reimagines

\footnotetext{
${ }^{7}$ Eduardo Viveiros de Castro's concept of mononaturalism refers to the hegemonic Western mindset that conceives nature as the universal ground of diversified human action. In this framework, a single, unified nature allows the emergence of multiple perspectives on political and cultural matters. However different, these multiple views share a common world, the external natural reality. In spite of its purported universalism, the provincial nature of Western mononaturalism emerges through the juxtaposition with the multinaturalism of Amerindian cosmologies in which humans and animals share subjectivity and agency but differ in their corporeal natures (Viveiros de Castro, "Cosmological Deixis and Amerindian Perspectivism").
} 
representative democracy as a "boundlessly pluralistic proceduralism" (Whiteside 202), a proliferation of assemblies, spokespersons, recognition of competencies and representational roles that enrolls hybrids into the body politics and grants the right of appeal to those who have been temporarily left out (Watson). Stengers's oblique reference to the possibility of composing with Gaia appears decidedly less committed to representative politics as well as to the image of a "common world." She is more attuned to non-representational activist practices that convey "the cosmopolitical stance that "we are not alone in the world" (Stengers, "The Cosmopolitical Proposal” 192).

If Latour provocatively declares "Like God, capitalism does not exist" (Latour, The Pasteurization of France, 173), Stengers addresses the question of vulnerability to capitalism and deliberately returns to Marx's critique of political economy while at the same time rejecting the Marxist fidelity to the narrative of progress. Much more than Latour, Stengers is interested in making sense of how particular modes of existence come undone under the pressure of normative forces or, in turn, express forms of resistance that open up the space for persistence and becoming. From this perspective, the possibility of composing with Gaia is a matter of care for movements and practitioners engaged in an experimental politics, one that is not guided by great narratives of universal emancipation but nevertheless resists capitalist eco-social relations. In other words, the gesture toward the composition with Gaia alludes to practices that resist what could be called "proprietary anthropocentrism," that is, the assumption that humans are bounded organisms engaging with the earth as a domain available to appropriation.

Stengers often refers to Starhawk's ecofeminist witchcraft as a practice that dares to make present that which causes practitioners to think and act, instead of re-instantiating politics as an exclusively human art. Combining ecofeminism, radical environmentalism and social justice activism, Starhawk and the witches of the Reclaiming tradition have been active participants of anti-nuclear blockades, direct action campaigns against the devastation of old-growth forests in Northern California, alterglobalization protests and, more recently, Occupy Wall Street. Through writings and a variety of rituals, including the spiral dance, the witches often invoke the Goddess, the name for a magic conception of matter and nature that was violently disqualified by the European witch-hunts of the sixteenth and seventeenth centuries and the rise of the Enlightenment ideals of human rationality. ${ }^{8}$

${ }^{8}$ In Dreaming the Dark (1982) Starhawk connects the European enclosures of the sixteenth and seventeenth centuries to the witch-hunts that undermined women's control over reproduction. In Caliban and the Witch (2004) Silvia Federici expands this argument to argue that capitalist primitive accumulation was sustained by the 
It would be tempting to dismiss the rituals of neo-pagan witches as spirituality that smacks of essentialism, or nostalgic remembrances of a lost enchanted world. But Stengers reads these rituals as ethico-aestheticpolitical experiments that, by invoking the Goddess, make present among practitioners "a cause without a representative" ("Introductory Notes on an Ecology of Practices" 195), without a spokesperson who speaks in its name. These techniques activate the power to think in a way "that it is no longer I, as a subject, as meant to belong to nobody but myself, who thinks and feels" (195). Magic catalyzes collectives of beings that are irreducible to the sum of autonomous individuals separated from each other and their vital milieu. At stake here is nothing less than the redefinition of political agency: the power to transform does not pertain to bounded subjects but to a more-than-human entanglement that enables collectives to think and invent.

Stengers's evocations of feminist witchcraft make uncomfortable reading for many Western activists and political theorists trained within the secularist tradition, including feminists who grew up with the refrain that closes Haraway's Cyborg Manifesto: "I would rather be a cyborg than a goddess" (Haraway, Simians, Cyborgs, and Women 181). Yet, as Maria Puig de la Bellacasa is quick to point out, Haraway's sentence is usually disconnected from the preceding words affirming that the cyborg and the goddess "are both bound in the spiral dance," (Puig de la Bellacasa, "Nothing Comes Without its World" 201). In spite of their seemingly oppositional valence, both figures attend to the more-than-human intricacies of world-making and thus contribute to the feminist project "to divest western philosophy of the fallacy of humanity's intractable autonomy" (Hird, "Waste, Landfills, and an Environmental Ethics of Vulnerability" 109). What matters in Stengers's reference to neo-pagan witchcraft is not whether one believes in the goddess or not. Not everyone might feel compelled to join the spiral dance. But these activist techniques point toward a very particular staging of the political scene, one that binds those involved in struggles together with existents that might be otherthan-human. Insofar as magic directs attention to world-making as an activity that is not limited to humans (Tsing, The Mushroom at the End of the World) it is a starting point, but by no means the only one, for enacting a feminist politics of composition with the earth.

\section{Conclusion}

appropriation of land, the criminalization of witches and the disqualification of an animistic conception of the world, the land, and the body that characterized the economies of subsistence in pre-modern Europe. 
In invoking Gaia, Stengers is engaging in a pragmatic operation that consists in conferring to this image of the earth the power to spark new modes of thinking how to exist together in the field of catastrophe. The exhortation to compose with Gaia is not addressed to a unitary and undifferentiated humanity, the Kantian people of the earth sharing a good common world, or the anthropos of the Anthropocene. On the contrary, it arises precisely from the hesitation about, if not the outright refusal of, these categories. Composition is a highly situated process, one faced with the enormous challenge of cultivating conviviality and endurance vis-à-vis neoliberal dispossession. This ongoing creation does not carry guarantees of redemption or the promise of reenchantment. It puts emphasis on "unknowns constituted by multiple divergent worlds and ... the articulations of which they could eventually be capable, as opposed to the temptation of a peace intended to be final" (Stengers, "The Cosmopolitical Proposal" 995). Invoking Gaia is a gesture toward a feminist politics of the earth, one that reorients attention from the anthropos of the Anthropocene, a figure that belies the false universality of Man, to the many earthly forces that partake in world-making projects.

\section{Works Cited}

BRAIDOTTI, Rosi. The Posthuman. Cambridge: Polity Press, 2013.

—. Transpositions. Cambridge: Polity Press, 2006.

BRAUN, Bruce and Whatmore Sarah, eds. Political Matter: Technoscience, Democracy and Public Life, Minneapolis: University of Minnesota Press, 2010.

CHAKRABARTY, Dipesh. "Postcolonial Studies and the Challenge of Climate Change." New Literary History, Vol. 43, N. 1 (2012): $1-18$.

COLEBROOK, Claire. Deleuze and the Meaning of Life. London: Continuum, 2010.

COOPER, Melinda. "Turbulent Worlds: Financial Markets and Environmental Crisis.” Theory, Culture and Society, Vol. 27, n.2-3 (2012): 167-190.

-. Life As Surplus: Biotechnology and Capitalism in the Neoliberal Era, Seattle: University of Washington Press, 2008. 
CRUTZEN, Paul. “Geology of Mankind.” Nature 415, 23 (2012).

DALlA Costa, Mariarosa and Chilese, Monica. Our Mother Ocean. Enclosures, Commons, and the Global Fishermen's Movement. Oakland: Common Notions/PM Press, 2014.

DALLA Costa, Mariarosa. "Rustic and Ethical." in Ephemera. Theory and Politics in Organization, Trans. Giuseppina Mecchia, Vol. 7(1) (2012): 107-116.

ELLIS, Ellis. "The Planet of No Return." Breakthough Journal, 2 (2012): 39-44.

FEDERICI, Silvia. Revolution at Point Zero: Housework, Reproduction, and Feminist Struggle. Oakland: Common Notions/PM Press, 2012.

-. Caliban and the Witch: Women, the Body, and Primitive Accumulation. Brooklyn: Autonomedia, 2004.

GAARD, Greta. "Ecofeminist Revisited: Rejecting Essentialism and Re-Placing Species in a Material Feminist Environmentalism." Feminist Formations, Vol. 23, N.2 (2011): 26-53.

GROSZ, Elizabeth. Chaos, Territory, Art. Deleuze and the Framing of the Earth. New York: Columbia University Press, 2008.

—. Nick of Time: Politics, Evolution, and the Untimely. Durham: Duke University Press, 2004.

GUHA, Ramachandra. "Radical American Environmentalism and Wilderness Preservation: A Third World Critique." Environmental Ethics, Vol. 11, N.1 (1989): 71-83.

HARAWAY, Donna. "Anthropocene, Capitalocene, Plantationocene, Chthulucene: Making Kin." Environmental Humanities, Vol. 6 (2015): 159-165.

-. Simians, Cyborgs, and Women. The Reinvention of Nature. New York: Routledge, 1991.

HEMMINGS, Clare. Why Stories Matter: The Political Grammar of Feminist Theory. Durham: Duke University Press, 2011.

HIRD, Myra. "Waste, Landfills, and an Environmental Ethic of Vulnerability." Ethics \& the Environment, Vol. 18, N.1 (2013): 105-124. 
-. "Indifferent Globality. Gaia, Symbiosis and 'Other-Worldliness'." Theory, Culture \& Society, Vol. 27 (2-3) (2010): 54-72.

LATOUR, Bruno. “An Attempt at a 'Compositionist Manifesto'." New Literary History, 41, 3 (2010): 471-490.

-. Politics of Nature: How to Bring the Sciences into Democracy. Trans. Catherine Porter. Cambridge: Harvard University Press, 2004.

-. The Pasteurization of France. Trans. Alan Sheridan and John Law. Cambridge: Harvard University Press, 1998.

LYNAS, Mark. The God Species. London: HarpersCollins, 2011.

LOVELOCK, James. The Revenge of Gaia: Earth's Climate Crisis and the Fate of Humanity, New York: Basic Books, 2006.

MARGULIS Lynn and Sagan Dorion. Dazzle Gradually: Reflections on the Nature of Nature, Chelsea Green Publishing, 2007.

MERCHANT, Carolyn. Earthcare: Women and the Environment. London: Routledge, 1996.

MOORE, Jason. Capitalism in the Web of Life: Ecology and the Accumulation of Capital. London and New York: Verso, 2015.

NIXON, Rob. Slow Violence and the Environmentalism of the Poor. Cambridge: Harvard University Press, 2011.

PRIGOGINE, Ilya and Stengers Isabelle. Order out of Chaos: Man's New Dialogue with Nature. New York: Bantam, 1984.

PUIG DE LA BELLACASA, Maria. "Nothing Comes Without its World. Thinking with Care." The Sociological Review, Vol. 60, N. 2 (2012): 198-212.

SHARP, Hasana. Spinoza and the Politics of Renaturalization. Chicago: University of Chicago Press, 2011.

SHIVA, Vandana. Earth Democracy. Justice, Sustainability and Peace. London: Zed Books, 2006.

STARHAWK. The Spiral Dance: A Rebirth of the Ancient Religion of the Great Goddess. New York: Harper \& Row, 1979. 
STEFFEN et al. "The Anthropocene: Conceptual and Historical Perspectives." Philosophical Transactions of the Royal Society A, 369 (2011): 842-867.

STENGERS Isabelle. In Catastrophic Times: Resisting the Coming Barbarism. Trans. Andrew Goffey. Ann Arbor: Open Humanities Press / meson press, 2015.

-. "Matters of Cosmopolitics: On the Provocations of Gaia. Isabelle Stengers in Conversation with Heather Davis and Etienne Turpin." Architecture in the Anthropocene. Encounters Among Design, Deep Time, Science and Philosophy. Ed. Etienne Turpin. Ann Arbor: Open Humanities Press, 2013. 171-182.

-. Thinking With Whitehead: A Free and Wild Creation of Concepts. Trans. Michael Chase. Cambridge: Harvard University Press, 2011.

-. Cosmopolitics I. Trans. Robert Bononno. Minneapolis: University of Minnesota Press, 2010a.

—. "Including Nonhumans in Political Theory: Opening Pandora's Box?" In Political Matter: Technoscience, Democracy and Public Life. Ed. Bruce Braun and Sarah Whatmore, Minneapolis: University of Minnesota Press, Minneapolis, 2010b. 3-34.

-. "Experimenting with refrains: Subjectivity and the challenge of escaping modern dualism." Subjectivity, Vol. 22 (2008) 38-59.

—. "The Cosmopolitical Proposal." Making Things Public: Atmospheres of Democracy. Ed Bruno Latour and Peter Weibel. Cambrige: MIT Press, (2005a) 994-1003.

-. "Introductory Notes on an Ecology of Practices." Cultural Studies Review 11.1 (2005b): 183-196.

-. The Invention of Modern Science. Trans. Daniel Smith, University of Minnesota Press, Minneapolis, 2000a.

-. "Another Look: Relearning to Laugh."” Hypatia:A Journal of Feminist Philosophy 15.4 (2000b): 58-40.

- Power and Invention. Situating Science. Trans Paul Bains, Minneapolis: University of Minnesota Press. 1997. 
SWYNGEDOUW, Erik. "Whose Environment? The End of Nature, Climate change and the Process of Post-Politicization." Ambiente \& Sociedade Campinas, Vol. XIV, N.2 (2011): 69-87.

TSING, Anna Lowenhaupt. The Mushroom at the End of the World. On the Possibility of Life in Capitalist Ruins. Princeton: Princeton University Press, 2015.

VIVEIROS DE CASTRO, Eduardo. "Cosmological Deixis and Amerindian Perspectivism." Journal of the Royal Anthropological Institute, Vol. 4 (3) (1998): 469-88.

WATSON, Matthew. "Cosmopolitics and the Subaltern Problematizing Latour's Idea of the Commons." Theory Culture \& Society, Vol. 28, N.3 (2011): 55-79.

WHITESIDE, Kerry. "A Representative Politics of Nature? Bruno Latour on Collectives and Constitutions." Contemporary Political Theory, Vol. 12 (2013): 185-205.

WILSON, Elizabeth. "Scientific Interest: Introduction to Isabelle Stengers, 'Another Look: Relearning to Laugh." Hypatia:A Journal of Feminist Philosophy 15.4 (2000): 58-40.

ZALASIEWICZ et al. "The New World of the Anthropocene." Environmental Science and Technology, 44 (2010): 2228-2231. 